6

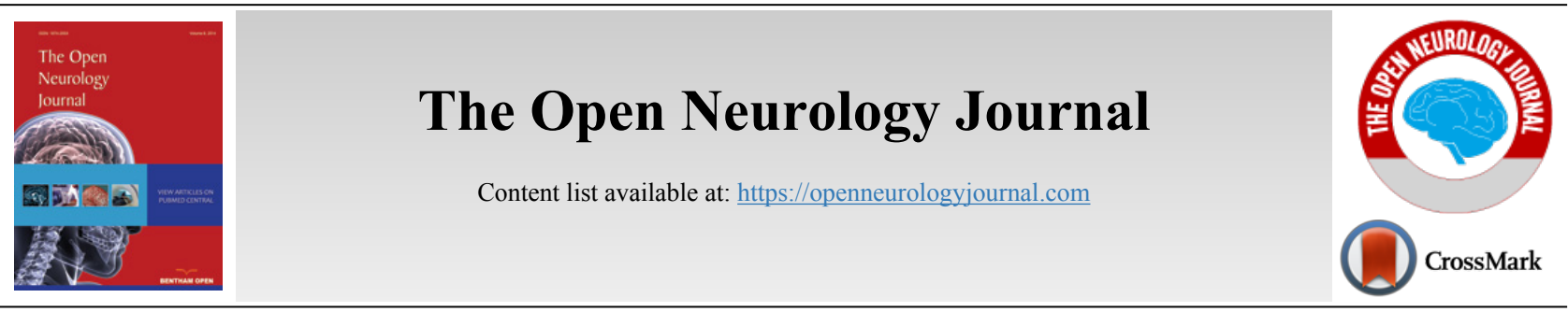

RESEARCH ARTICLE

\title{
Correlation between Serum Vitamin A and D Levels in Acute Phase Ischemic Stroke and Clinical Outcome
}

\author{
Alfansuri Kadri ${ }^{1 * *(D)}$, Hasan Sjahrir ${ }^{1}$, Rosita J. Sembiring ${ }^{2}$ and Muhammad Ichwan ${ }^{3}$ \\ ${ }^{1}$ Neurology Department, Faculty of Medicine, Universitas Sumatera Utara Adam Malik General Hospital, Medan, Indonesia \\ ${ }^{2}$ Clnical Pathology Department, Faculty of Medicine, Universitas Sumatera Utara Adam Malik General Hospital, Medan, Indonesia \\ ${ }^{3}$ Pharmacology Department, Faculty of Medicine, Universitas Sumatera Utara Adam Malik General Hospital, Medan, Indonesia
}

\begin{abstract}
:
Background:

In the last decade, a number of studies have examined the relationship between serum vitamin D concentration and the risk of cerebrovascular events. Besides vitamin D, the latest evidence shows that vitamin A is also a risk factor for cerebrovascular disease. Vitamin A and its derivatives act biologically via specific nuclear receptors that regulate gene transcription. Vitamin A receptors can also interact with other nuclear receptors that have neuroprotective effects such as vitamin D, against stroke. Although many studies suggested the synergism of vitamin A and D, there is still no study that evaluates their levels simultaneously in acute phase ischemic stroke, and the relationship to outcome.
\end{abstract}

Objective:

The objective of this study was to analyze the correlation between serum vitamin A and D levels on admission in Acute Ischemic Stroke patients and clinical outcome by using the National Institutes of Health Stroke Scale (NIHSS).

Methods:

A prospective cohort study was conducted, and samples were followed since the diagnosis of acute-phase Ischemic Stroke was established until the clinical outcome of day 14 after stroke onset. A total of 50 subjects enrolled for this study would be examined for serum levels of vitamins A and D on admission, and on the $14^{\text {th }}$ day were assessed for NIHSS as a clinical outcome.

Results:

From 50 research subjects, the mean of vitamin A and D level in the acute phase of Ischemic Stroke was $463.35 \pm 116.97 \mu \mathrm{g} / \mathrm{L}$ and $21.65 \pm 6.51$ $\mathrm{ng} / \mathrm{mL}$, respectively. By using the Spearman's correlation test, it was found that the acute phase vitamin A level and NIHSS on day 14 had a significant and strong correlation with $\mathrm{p}=0.045(\mathrm{r}=-0.672)$. Along with it, vitamin $\mathrm{D}$ serum levels and NIHSS also had a significant and strong correlation with $\mathrm{p}=0.026(\mathrm{r}=-0.754)$. Both of these results showed that vitamin A and D had an inverse association with NIHSS, meaning that the higher vitamin A and D serum levels, the better the clinical outcome would be.

\section{Conclusion:}

Both serum vitamin A and D levels in the acute phase of Ischemic Stroke was correlated strongly with short time clinical outcome. The higher vitamin $\mathrm{A}$ and $\mathrm{D}$ serum levels in the acute phase, the better the clinical outcome would be for Ischemic Stroke patients.

Keywords: Vitamin A, Vitamin D, Ischemic Stroke, Outcome, NIHSS, Cerebrovascular disease.

\section{INTRODUCTION}

Stroke is one of the cerebral vascular diseases, which is ca-

* Address correspondence to this author at Neurology Department, Faculty of Medicine, University of Sumatera Utara, No. 5, Dr. T. Mansyur Road, Medan, 20155, Indonesia; Tel: +62 618211045 , Mobile phone: +628126010064 ;

E-mail: alfansurikadri@yahoo.com tegorized as the third cause of death after heart disease and malignancy and is the number one cause of long-term disability in the world. According to data from the World Health Organization (WHO), 15 million of the world's population experience stroke each year. Of this number, 5 million died, and 5 million suffered permanent disability $[1,2]$. 
According to data from Basic Health Research (RISKESDAS), stroke is a syndrome that ranks number one of non-communicable diseases in Indonesia, which causes death and disability of $15.4 \%$. There was an increase in stroke prevalence based on interviews (based on the answers of respondents who had been diagnosed with health problems and symptoms) from 8.3 per 1000 (2007) to 12.1 per 1000 (2013). Stroke prevalence in Indonesia based on the diagnosis of health personnel is 7 per 1000 and diagnosed by health, or symptom personnel is 12.1 per 1000 . Stroke prevalence is based on the highest diagnosis of health in North Sulawesi (10.8\%o), followed by Special Region (DI) Yogyakarta (10.3\%o), Bangka Belitung and the Special Capital Region (DKI) Jakarta, respectively 9.7 per 1000 . The prevalence of stroke is based on diagnosed health problems and the highest symptoms are in South Sulawesi (17.9\%), Jogjakarta (16.9\%), Central Sulawesi (16.6\%), followed by East Java at 16 per mile [3, 4].

The process of atherosclerosis is characterized by arterial remodeling that causes progressive subendothelial plaque accumulation, through a complex set of cellular processes that occur in the arterial wall with inflammation playing an important role in various phases. In the last decade, a number of studies have examined the relationship between serum 25hydroxyvitamin D concentration and cardiovascular risk. The results show that hypovitaminosis D can cause atheroma and supplementation of vitamin D can prevent the risk of vascular disease [5].

Besides vitamin $\mathrm{D}$, the latest evidence shows that vitamin A (retinol) is a risk factor for cardiovascular disease and mortality. Plasma retinol levels are inversely proportional to the risk of cardiovascular disease mortality. Research has shown that patients with coronary heart disease or atherosclerosis show retinol levels that are significantly lower than controls [6]. Vitamin A is a nutrient that affects the immune response through multiple mechanisms. For example, from the results of the study, vitamin A appears to help produce B cells from Immunoglobulin A (IgA) by upregulating IL-6 [7]. Retinoic Acid (RA), a bioactive derivative of vitamin A and an important differentiation factor during the development of vertebrates, has been found to participate in neuron and vascular development. Increasing evidence shows that RA signaling pathways provide an important mechanism for the regulation of the Blood Brain Barrier (BBB) in the neurovascular system. The effect of RA protection on BBB further reduces cerebral damage in Ischemic Stroke. The development of future clinical experiments can identify RA as a potential target for the treatment of neurovascular disease $[8,9]$. Retinol and its derivatives act biologically via specific nuclear receptors that regulate gene transcription. RA receptors can also interact with other nuclear receptors that have neuroprotective effects such as neuroprotective vitamin D against stroke. In addition, the nucleus receptors can also form dimers with thyroid hormone receptors, and thyroid hormone derivatives are protective against tissue infarction. Thus, the neuroprotective effects of retinol and RA can be mediated by the formation of heterodimers with other nuclear receptors [10]. Although there are many studies that suggested the synergism of vitamin $\mathrm{A}$ and $\mathrm{D}$, there is still no study that evaluates their levels simultaneously in acute phase ischemic stroke, and the relationship to outcome. Thus, this study will analyze the correlation between serum vitamin A and D levels on admission in Acute Ischemic Stroke patients and clinical outcome by using the National Institutes of Health Stroke Scale (NIHSS).

\section{Table 1. Baseline data.}

\begin{tabular}{|c|c|}
\hline Age (Year; Mean \pm SD) & $\mathbf{6 6 . 8 5} \pm \mathbf{5 , 3 2}$ \\
\hline Sex (n; \%) & 31 \\
$\cdot$ Male & 19 \\
$\bullet$ Female & \\
\hline Smoking $(\mathrm{n} ; \%)$ & 33 \\
$\cdot$ Yes & 17 \\
$\cdot$ No & 23 \\
\hline Alcohol (n; \%) & 27 \\
$\cdot$ Yes & \\
\hline No & $128 \pm 11.54$ \\
\hline Blood Sugar Level (mg/dL; Mean \pm SD) & 28 \\
\hline Dyslipidemia (n; \%) & 22 \\
$\cdot$ Yes & $463.35 \pm 116.97$ \\
\hline No & $21.65 \pm 6.51$ \\
\hline Vitamin A Serum $(\mu \mathrm{g} / \mathrm{L} ;$ Mean \pm SD) & $13.42 \pm 1.25$ \\
\hline NIHSS on admission $($ Mean \pm SD) & $11.36 \pm 2.51$ \\
\hline NIHSS on day 14 (Mean \pm SD) & \\
\hline
\end{tabular}

\section{MATERIAL AND METHODS}

Patients were selected from the stroke unit of the Neurology Department, Adam Malik General Hospital in Medan - Indonesia, between the period of May 2018 to February 2019. The design of this study was a prospective cohort, and overall study samples were followed since the diagnosis of acute-phase Ischemic Stroke was established until the clinical outcome of day 14 after stroke onset. There was a total of 50 subjects enrolled in this study. All of the standard treatments for Ischemic Stroke were given equally for all subjects, and cardioembolic stroke was excluded. Patients who was currently consuming supplements containing vitamin A or D on admission were also excluded, as to exclude any possible interaction with vitamin serum levels. Clinical outcome was determined using the National Institute of Health Stroke Scale (NIHSS). Subjects who met the inclusion criteria would be examined for serum levels of vitamin A and D. On the $14^{\text {th }}$ day, all subjects were assessed for NIHSS as a clinical outcome. The study was conducted in accordance with the Declaration of Helsinki (1964), and the protocol was approved by the Health Research Ethical Committee, Medical Faculty, University of Sumatera Utara, number: 392/TGL/KEPK FK-USU-RSUP HAM/2018.

\section{RESULTS}

Table 1 shows the baseline characteristics of subjects and also the mean serum level of vitamin $\mathrm{A}$ and $\mathrm{D}$ on admission. In all examined subjects, the mean serum level of vitamin A and $\mathrm{D}$ in the acute phase of Ischemic Stroke were $463.35 \pm 116.97$ $\mu \mathrm{g} / \mathrm{L}$ and $21.65 \pm 6.51 \mathrm{ng} / \mathrm{mL}$, respectively (Table 1). By using the Spearman's correlation test, it was found that the acute phase vitamin A level and NIHSS on day 14 had a significant and strong correlation with $\mathrm{p}=0.045(\mathrm{r}=-0.672)$. Along with 
it, vitamin D levels and NIHSS also had a significant and strong correlation with $\mathrm{p}=0.026(\mathrm{r}=-0.754)$, as shown in Table 2. Both of these results showed that vitamin A and D had an inverse association with NIHSS, meaning that the higher vitamin $\mathrm{A}$ and $\mathrm{D}$ serum levels, the better the clinical outcome will be.

Table 2. Correlation between vitamins serum level and NIHSS on day 14.

\begin{tabular}{|c|c|c|}
\hline- & \multicolumn{2}{|c|}{ NIHSS on Day 14 } \\
\hline Serum Vitamin A & $\mathrm{r}$ & $\mathrm{p}^{*}$ \\
\cline { 2 - 3 } Serum Vitamin D & -0.672 & 0.045 \\
& -0.754 & 0.026 \\
\hline
\end{tabular}

\section{DISCUSSION}

The results of this study indicated that serum levels of vitamins $\mathrm{A}$ and $\mathrm{D}$ in ischemic stroke patients on admission appeared to have a significant correlation to NIHSS on day 14 . Various studies have also shown that vitamins A and D are very important for healthy immune responses on mucosal surfaces. These vitamins are interrelated because they differ binding to heterodimeric receptors (AR-RXR; VDR-RXR), which, in turn, affect the expression of immune response genes $[11,12]$.

In the last decade, a number of studies have examined the relationship between serum vitamin $\mathrm{D}$ concentration and cardiovascular risk. The results show that hypovitaminosis D can cause atheroma and supplementation of vitamin D can prevent the risk of vascular disease [5] Vitamin D can act as neuroprotection through a variety of mechanisms, such as antioxidant / anti-inflammatory mechanisms, inhibition of nitric oxide synthase, regulation of neuronal calcium, detoxification pathways or increased nerve conduction [13]. Over time, it is seen that vitamin D deficiency often occurs throughout the world and is associated with several chronic health problems, including cerebrovascular [14 - 16]. In vitro and studies in animals, vitamin D deficiency affected the activity / expression of macrophages and lymphocytes on atherosclerotic plaques that cause chronic inflammation in the arterial wall. Furthermore, vitamin D has also been seen as a potent inhibitor of foam cell formation, also triggering angiogenesis in endothelial cells. In particular, vitamin D modulates the immune system / inflammation by regulating the production of inflammatory cytokines and inhibits proinflammatory cell proliferation, both of which are important in the pathogenesis of systemic and vascular inflammation that causes atherogenesis $[5,14]$.

Besides vitamin $\mathrm{D}$, the latest evidence shows that vitamin A (retinol) is a risk factor for cardiovascular disease and mortality. Plasma retinol levels are inversely proportional to the risk of cardiovascular disease mortality. Research has shown that patients with coronary heart disease or atherosclerosis show retinol levels that are significantly lower than controls [6]. Vitamin $\mathrm{A}$ is a nutrient that affects the immune response through multiple mechanisms. For example, from the results of the study, vitamin A appears to help produce B cells from Immunoglobulin A (IgA) by upregulating IL-6 [7].
Research conducted by Ikeda et al. in 2010 found that vitamin D synergistically suppressed Th17 cell formation through a combination with all-trans retinoic acid (ATRA). In addition, it was also found that vitamin D and ATRA significantly inhibited the development of human Th17 cells from CD4 + T cells. 1,25D3 and ATRA effectively suppress the expression of mRNA from IL-1R1, IL-21R, IL-23R, RORC, and AHR in human T cells. Thus, vitamin D and ATRA have a synergistic effect on Th17 cell formation, indicating that a combination of vitamin D and vitamin A will have a strong therapeutic effect on the immune system. Retinoid signaling is mediated through retinoic acid receptors (RAR) and retinoid X receptors (RXR), which generally form RXR / RAR heterodimers, and vitamin D signaling is transduced by VDR and RXR. As vitamin D and ATRA share RXR as a general receptor, and its function in Th17 is considered similar, the study tested whether vitamin D and ATRA had an additive or synergistic effect on Th17. As expected, the combination of $1,25 \mathrm{D}_{3}$ with ATRA greatly inhibits Th17 cells compared to the same dose for vitamin D or ATRA alone [17].

Retinoic Acid (RA), a bioactive derivative of vitamin A and an important differentiation factor during the development of vertebrates, has been found to participate in neuron and vascular development. Increasing evidence shows that RA signaling pathways provide an important mechanism for the regulation of the Blood-Brain Barrier (BBB) in the neurovascular system. The effect of RA protection on BBB further reduces cerebral damage in Ischemic Stroke. The development of future clinical experiments can identify RA as a potential target for the treatment of neurovascular disease [8]. Vitamin D Receptor (VDR), a member of the nuclear receptor superfamily, mediates the action of the biological form of vitamin D. After activation, the vitamin D receptor (VDR) binds specifically to the Vitamin D Response Element (VDRE), as heterodimer with the Retinoid X Receptor (RXR), and then modulate the target gene expression. Activation of VDR by vitamin D or its analogues has been reported to show the protective effects of atherosclerosis in several animal experiments $[5,18]$.

Those previous researches supported the findings in this current research. This research found that there were strong correlations between both vitamin $\mathrm{A}$ and $\mathrm{D}$ on admission and NIHSS on day 14, where the correlation was reversed; the higher the concentration of vitamins $\mathrm{A}$ and $\mathrm{D}$, the lower the value of NIHSS. This supported the theory of work synergism between vitamin $\mathrm{A}$ and vitamin $\mathrm{D}$, that the combination of vitamins $\mathrm{A}$ and $\mathrm{D}$ will make their performance increased, compared to when alone. Ultimately, both serum vitamin A and D levels in the acute phase of Ischemic Stroke was found to be correlated strongly with the short-term clinical outcome of 14 days.

\section{CONCLUSION}

Both serum vitamin A and D levels in the acute phase of Ischemic Stroke was correlated strongly with short time clinical outcome. The higher vitamin A and D serum levels in the acute phase, the better the clinical outcome would be for Ischemic Stroke patients. 


\section{ETHICS APPROVAL AND CONSENT TO PARTI- CIPATE}

The study has been approved by the University of Sumatera Utara, Indonesia with approval number 392/TGL/KEPK FK USU-RSUP HAM/2018.

\section{HUMAN AND ANIMAL RIGHTS}

No Animals were used in this research. All human research procedures were followed in accordance with the ethical standards of the committee responsible for human experimentation (institutional and national), and with the Helsinki Declaration of 1975, as revised in 2013.

\section{CONSENT FOR PUBLICATION}

Informed consent was obtained from all participants.

\section{AVAILABILITY OF DATA AND MATERIALS}

Not applicable.

\section{FUNDING}

The research and publication of this research is funded TALENTA grant no. 4168/UN5.1.R/PPM/2018.

\section{CONFLICT OF INTEREST}

The authors declare no conflict of interest, financial or otherwise.

\section{ACKNOWLEDGEMENTS}

Declared none.

\section{REFERENCES}

[1] Brenner ZR, Miller AB, Ayers LC, Roberts A. The role of vitamin D in critical illness. Crit Care Nurs Clin North Am 2012; 24(4): 527-40. [http://dx.doi.org/10.1016/j.ccell.2012.07.009] [PMID: 23089658]

[2] Chehaibi K, Trabelsi I, Mahdouani K, Slimane MN. Correlation of Oxidative Stress Parameters and Inflammatory Markers in Ischemic Stroke Patients. J Stroke Cerebrovasc Dis 2016; 25(11): 2585-93. [http://dx.doi.org/10.1016/j.jstrokecerebrovasdis.2016.06.042] [PMID: 27474112]

[3] Gofir A. Pengantar Manajemen Stroke Komprehensif. Jogjakarta: Pustaka Cendikia Press 2007.

[4] Guilland JC. Les interactions entre les vitamines A, D, E et K : Synergie et/ou compétition. OCL -. Ol Corps Gras Lipides 2011; 18(2): 59-67.

[http://dx.doi.org/10.1051/ocl.2011.0376]
[5] Ikeda U, Wakita D, Ohkuri T, et al. 1 $\alpha, 25$-Dihydroxyvitamin D3 and all-trans retinoic acid synergistically inhibit the differentiation and expansion of Th17 cells. Immunol Lett 2010; 134(1): 7-16. [http://dx.doi.org/10.1016/j.imlet.2010.07.002] [PMID: 20655952]

[6] Jones BG, Oshansky CM, Bajracharya R, et al. Retinol binding protein and vitamin $\mathrm{D}$ associations with serum antibody isotypes, serum influenza virus-specific neutralizing activities and airway cytokine profiles. Clin Exp Immunol 2016; 183(2): 239-47.

[http://dx.doi.org/10.1111/cei.12718] [PMID: 26425827]

[7] Kong L, Wang Y, Wang XJ, et al. Retinoic acid ameliorates bloodbrain barrier disruption following ischemic stroke in rats. Pharmacol Res 2015; 99: 125-36.

[http://dx.doi.org/10.1016/j.phrs.2015.05.014] [PMID: 26066585]

[8] Lakhan SE, Kirchgessner A, Tepper D, Leonard A. Matrix metalloproteinases and blood-brain barrier disruption in acute ischemic stroke. Front Neurol 2013; 4: 32.

[http://dx.doi.org/10.3389/fneur.2013.00032] [PMID: 23565108]

[9] Makariou SE, Michel P, Tzoufi MS, Challa A, Milionis HJ. Vitamin D and stroke: promise for prevention and better outcome. Curr Vasc Pharmacol 2014; 12(1): 117-24

[http://dx.doi.org/10.2174/15701611113119990119] [PMID: 22724468]

[10] Min K, Min J. Relation of serum vitamin A levels to all-cause and cause-specific mortality among older adults in the NHANES III population 2014.

[http://dx.doi.org/10.1016/j.numecd.2014.06.004]

[11] Ministry of Health of the Republic of Indonesia.. Riset Kesehatan Dasar. Badan Penelitian dan Pengembangan Kesehatan Kementerian Kesehatan 2007.

[12] Ministry of Health of the Republic of Indonesia.. Riset Kesehatan Dasar. Badan Penelitian dan Pengembangan Kesehatan Kementerian Kesehatan 2013.

[13] Muscogiuri G, Annweiler C, Duval G, et al. Vitamin D and cardiovascular disease: From atherosclerosis to myocardial infarction and stroke. Int J Cardiol 2017; 230: 577-84

[http://dx.doi.org/10.1016/j.ijcard.2016.12.053] [PMID: 28043680]

[14] Nargesi AA, Heidari B, Esteghamati S, et al. Contribution of vitamin $\mathrm{D}$ deficiency to the risk of coronary heart disease in subjects with essential hypertension. Atherosclerosis 2016; 244: 165-71. [http://dx.doi.org/10.1016/j.atherosclerosis.2015.11.020] [PMID: 26647372]

[15] Penkert RR, Jones BG, Häcker H, Partridge JF, Hurwitz JL. Vitamin A differentially regulates cytokine expression in respiratory epithelial and macrophage cell lines. Cytokine 2017; 91: 1-5.

[http://dx.doi.org/10.1016/j.cyto.2016.11.015] [PMID: 27940088]

[16] Pike JW, Meyer MB, Martowicz ML. New techniques in transcription research extend our understanding of the molecular actions of the Vitamin D hormone. IBMS boneKEy 2009; 6(5): 169-80. [http://dx.doi.org/10.1138/20090376]

[17] Ren W, Gu Y, Zhu L, et al. The effect of cigarette smoking on vitamin $\mathrm{D}$ level and depression in male patients with acute ischemic stroke. Compr Psychiatry 2016; 65: 9-14.

[http://dx.doi.org/10.1016/j.comppsych.2015.09.006]

[PMID: 26773985]

[18] Sato Y, Meller R, Yang T, Taki W, Simon RP. Stereo-selective neuroprotection against stroke with vitamin A derivatives. Brain Res 2008; 1241: 188-92.

[http://dx.doi.org/10.1016/j.brainres.2008.09.020] [PMID: 18824156]

C) 2020 Kadri et al.

This is an open access article distributed under the terms of the Creative Commons Attribution 4.0 International Public License (CC-BY 4.0), a copy of which is available at: (https://creativecommons.org/licenses/by/4.0/legalcode). This license permits unrestricted use, distribution, and reproduction in any medium, provided the original author and source are credited. 